University of California, Hastings College of the Law UC Hastings Scholarship Repository

Faculty Scholarship

2002

\title{
Getting to Survivance: An Essay About the Role of Mythologies in Law
}

Jo Carrillo

UC Hastings College of the Law, carrillo@uchastings.edu

Follow this and additional works at: http://repository.uchastings.edu/faculty_scholarship

Part of the Law and Society Commons

\section{Recommended Citation}

Jo Carrillo, Getting to Survivance: An Essay About the Role of Mythologies in Law, 25 PoLAR 37 (2002).

Available at: http://repository.uchastings.edu/faculty_scholarship/66

This Article is brought to you for free and open access by UC Hastings Scholarship Repository. It has been accepted for inclusion in Faculty Scholarship

by an authorized administrator of UC Hastings Scholarship Repository. For more information, please contact marcusc@uchastings.edu. 


\section{Faculty Publications \\ UC Hastings College of the Law Library}

Author: Jo Carrillo

Source: $\quad$ PoLAR: The Political \& Legal Anthropology Review

Citation: 25 PoLAR 37 (2002).

Title: Getting to Survivance: An Essay About the Role of Mythologies in Law

Originally published in POLAR: THE POLITICAL \& LEGAL ANTHROPOLOGY REVIEW. This article is reprinted with permission from POLAR: THE POLITICAL \& LEGAL ANTHROPOLOGY REVIEW and American Anthropological Association on behalf of the Association for Political and Legal Anthropology. 
SYMPOSIUM

Jo Carrillo

University of California,

Hastings College of the Law

\section{Getting to Survivance: An Essay about the Role of Mythologies in Law}

Narrative and mythology are powerful forces in history. They are also powerful in law, which is itself a narrative tradition. Narrative and mythology are meant to illuminate the mystery we find ourselves in, while history is regarded as serving a different, more explanatory function.

Law is its own form of narrative, or story telling, containing within its terms discrete histories. Judges write the narrative of law, as legal disputes find resolution in courts. In important cases, judges write legal opinions, explaining the rationale behind their decisions. Judicial decisions form a core part of the narrative or discourse of law. Just as a non-legal narrative gets fixed by time and retelling, legal narrative gets fixed by power. To be sure, the stories of law hold magic; some of the most celebrated opinions take on the status of myth, thus becoming mythologies of power, marred by the force of ideology (Foucault 1972; Keenan 1997).

This essay concerns itself with two nodes in the network of the continuous discourse that is law (Foucault 1972:23-27). First, I describe how and by what means first year law students get introduced to the indigenous presence in North America. Second, I discuss the evolutionary anthropological framework that law-school casebooks implicitly employ. In fact, this essay focuses specifically on law-school property casebooks and how they use the famous case of Johnson v. McIntosh to teach law students lessons about liberalism (Johnson v. McIntosh 1832). Johnson v. McIntosh was one of the first cases before the United States Supreme Court to raise the issue of Indian ownership rights to land. This essay discusses how Johnson $v$. McIntosh, as presented in the law-school property casebook, uses a "symbolic indian," or what Vizenor calls a "simulated indian" (Vizenor 1999). The symbolic indian (lower case i) is an image, not an empirical rendering of actual indigenous persons or communities. It is a creation, a fiction, a pedagogical device that does not speak to the conditions of contemporary indigenous communities in the U.S. or abroad. Indeed the symbolic indian cannot speak to the conditions of contemporary indigenous communities because it is a fiction created exclusively from the documents of the colonizer (Foucault 1972).

The symbolic indian is a node in the network of a continuous discourse in law about familiar binaries such as the superiority of liberalism over tribalism, of private property over communal property, of the agricultural use of land over other uses, particularly hunting, and so forth. It works where the rational legal system's network gives way to the irrational, which is to say to symbolism. That is, the symbolic indian works at sites in the legal discourse that cannot be analyzed with ordinary rational methods (Legendre 1998). It works where "memory fades and mythological interpretations of the beginnings of human society take hold in the popular imagination" (Deloria Jr. and Wilkins 1999:vii). Thus the symbolic indian represents obstacles to rational thought in at least three distinct ways.

Copyright (C) 2002, American Anthropological Association 
First, the symbolic indian, when used in the context of legal pedagogy, suggests little need to discuss the current legal concerns of actual indigenous communities in the U.S. or abroad (Vizenor 1999). This is because the symbolic indian freezes the image that future generations of lawyers have of indigenous communities. Thus, the implication of the symbolic indian is that the legal issues surrounding actual indigenous communities are no longer up for discussion because they belong in the long resolved historical and legal past. Second, the symbolic indian is an image that makes the historical past the frame for measuring the authenticity of contemporary indigenous communities and their legal claims. Thus, in order to be authenticated as indigenous under American law, indigenous communities find themselves in the awkward position of having to prove that they are indeed relics of the past, or that they comport with popular current stereotypes of the indian (Carrillo 1996, 1998; Clifford 1988). Third, the simulated indian is so thoroughly imbedded in legal ideology that it is reproduced in both expressly socioevolutionary texts as well as in texts that would declare themselves opposed to the socioevolutionary frame. The result is that no matter the subject position of the legal author, whether it be sympathetic to indigenous concerns or more distant from them, actual indigenous legal concerns get omitted from discussion of key legal issues (Vizenor 1999). In this way, actual indigenous communities are put into a difficult position of legal subjectivity, one whose parameters are set by symbolism and stereotype.

\section{Theoretical Frame}

By most accounts the first semester of law school is a difficult experience. Students are introduced to the basic law school curriculum, which consists of property, torts, contracts, criminal law, and civil (court) procedure. Property alone is an overwhelming course, reaching back to feudal England and extending forward to a world, for example, where genetic information is routinely commodified. One of the first lessons of property law concerns the acquisition of property, meaning how it is that resources and things come to be regarded as private property in the first instance. Early in the acquisition lesson, as well as early on in the property law casebook, students read the case of Johnson v. McIntosh for an introduction to the labor theory of property, not (ironically) for an introduction to issues related to conquest. This is, of course, assuming the case is even deemed important enough to assign at all.

Like all casebooks, property law casebooks closely adhere to a standard format. In the casebook format students read individual legal cases organized topically, not chronologically. In one casebook section a student might read a case decided in the sixteenth century followed by a case decided in the early or even late twentieth century. Editorial notes and questions follow principal cases. Because the state of the law is in constant flux, the casebook format does not require state by state treatment of an issue either in terms of case selection or of editorial notes. Instead, any given topic is typically illustrated with somewhere between one and five (or more) principle cases. The editors use the notes, not the principle cases, to report nuance and to signal differences in legal approaches among jurisdictions. Also, the casebook format rarely makes an effort to construct for students the complex social relations behind the issues. So, for example, in notes about the property rights of unmarried cohabitants, a controversial issue in property law, the topic might get neatly divided into "married" and "unmarried" couples, rather than richly described in any sort of multiversality. Similarly in the notes following Johnson v. McIntosh, the topic gets divided into the indian and the american, rather than richly described in terms of the complex social relations that existed and still exist between and within indigenous and non-indigenous communities. 
In terms of standard law-school presentation, property class is the single point at which firstyear law students study issues of concern to indigenous communities. But as taught in the labor theory section of the property casebook, and as introduced by the case of Johnson v. Mclntosh, the image of the indigenous that students get is not one of nuance or actuality, but rather one of symbolism.

It is my view that the symbolic indian is a fiction hardened into ideology. The symbol of the indian that the law relies on is presented repetitively and consistently over time as part of a utilitarian project. It is also resistant to questioning and, ironically, to logical analysis. For this reason, I call the symbolic indian a "disabling certitude" (Carrillo 2000). Disabling certitudes are ideas about which we are frighteningly certain; ideas which we protect from the light of reason or analysis. They are presumptions that never change, views that occlude our vision, admonitions against questioning. Disabling certitudes are the same as simulations of the indian, but they are simulations embedded in the narrative of law, and backed by the power of the state. As such, they have the potential to affect our material existence in a direct way.

Disabling certitudes give rise to a particular image of the indian - the indian in the context of liberalism, meaning the indian as a foil for modernity, the indian who shows americans of european ancestry who they are not, or what they have "moved beyond." The symbolic indian proves to "us" that "we" are civilized, that "we" are not "them," as "we" have progressed away from the animal, the group, the communal, and toward the radical individualist of the economist. The indian I' $m$ describing here - the one who lives in the property casebook's narrative -is represented as premodern, hopelessly back ward, somewhere closer in evolutionary frames to animal than to human (Michaelson 1999). By relying on the image of the symbolic indian, property casebooks adopt an evolutionary anthropological frame. Both the symbolic indian and the frame impart a lesson of modernity, insuring and assuring beginning law students (no matter their performance on exams) that they are indeed steeped in modernism and the liberal ideology that undergirds twentieth-century American law. The symbolic indian teaches students central lessons of liberalism such as the need for private property, the exaltation of the individual over the group, the importance of the right to exclude over the right to be included, and the like. At its core, this symbol of the indian, linked as it is to the symbolic node of evolutionary anthropology, also teaches a troubling and dangerous lesson of white supremacy. For it is consistently the symbolic indian's lack that gets juxtaposed against the white american's plenty to make the point that nature and history (now rendered a force of divine agency) favor those who have and take over those who do not have or, for whatever reason, will not take.

The legal materials I discuss here use the indian as a central character, either expressly or by implication. But they do not concern themselves with the interests, concerns, or issues as articulated, presented, or defined by indigenous communities. Indeed, what these materials have in common is that while they are about indians, they have nothing to do with actual indigenous experience. Moreover, they lack what Vizenor (1999) calls the indigenous imagic presence, meaning not only are they not about the indigenous, they are not shaped or defined by indigenous actors, beliefs, or images. Rather, they are materials imposed upon the indigenous in the guise of a fair weighing of interests, or perhaps in the guise of a dialogue. In addition, the lesson of white supremacy, or at least of the need for racialist definitions, is in a troubling way at the core of the materials I write about in this essay, especially to the degree that those 
materials start from the premise that human beings break down into distinct "races" or people. races that in Chief Justice Marshall's narrative must be kept separate (Johnson 1832). Within the idea of separation is the implicit concern for purity, not the purity of the indian, but rather the racial purity of the white (Johnson 1832).

Characters, by their very nature, are sketches or approximations of the actual. One could argue that while the indian might be a symbol, or a simulation, so is the white. White concerns, one could say, are as stereotyped as the indian concerns in classic legal texts. The difference is that in these texts the white position, while characterized as a problematic monolithic space, is assigned the possibility of redemption, whereas the indian position is not. In these texts, whites are moving into the future, while indians remain in the past; whites are assigned the quality of vision, indians are blinded by tradition; whites are described as deserving, no matter how many atrocities they may have committed against indigenous communities, indians are not deserving primarily because. the implication is, they do not hold to rules about efficient and privatized uses of land. In short, these materials are a continuing theme in a two-century-long discourse, not discrete texts ivritten at specific points in historical time.

What has hardened into dogma, or disabling certitudes-ideological lessons embedded in legal narrative-are both the symbol of the indian juxtaposed against the white and the rules for how one presents indigenous/european disputes. In both cases, the symbol or the case is presented from the point of view of the american-european, not from the indigenous american, as the former point of view is, under these rules, deemed the most valid, if not the only valid view. The indian in this framework becomes easily definable; while the position of whiteness defies categorization. Whether indianness gets measured by blood, or by political recognition, or by some other criterion, in the end, the symbolic indian is defined not by those to whom the label applies, but rather by those who are imposing the label (Clifford 1988). What Vizenor (1999) calls the indigenous imagic presence is ironically absent.

The lessons of the symbolic indian are so time-worn that today they are transmitted and accepted unconsciously. Yet to understand the symbols and the rules by which the symbols are stated, as well as what gets left unstated by this process, is important because it is one way to weaken the fabric of symbolism and thus to open up an analytic discussion of topics that are today excluded from the law-school curriculum. Such topics include, for instance: the genocidal and racist threads of U.S. history vis-à-vis indigenous peoples; the forced removal of indigenous communities from their homelands; the role of boarding schools in the dispossession of indigenous communities; the theft of indigenous property by the U.S. and its settlers; and the role of lawyers and the law in upholding a legal regime that gave way to these types of injustices against indigenous peoples.

What follows are two examples from law-school teaching materials. Both examples use the symbol of the indian to make their point. The first example is from Chief Justice John Marshall's legal opinion in Johnson v. McIntosh. The second example is taken from the 1997 edition of a widely used property law casebook.

\section{Johnson v. McIntosh (1832)}

The primary task of the first year of law school is to inculcate students with the values of the law by teaching them how to read and analyze cases as legal professionals would. While there is a focus on logic and rules, students also learn historical and policy justifications for the law. 
Johnson $v$. McIntosh figures prominently in the first few days of the first year property course as a principal case study (assuming of course it is even assigned at all). The case was part of a trilogy of Indian law cases in which Chief Justice Marshall set up the basic structure of an area known today as federal Indian law (see also Cherokee Nation v. Georgia 1831; Worcester v. Georgia 1832). In Johnson v. McIntosh, Chief Justice Marshall held that indigenous communities have a possessory right to the soil that can be extinguished by federal, but not state, action. In Cherokee and Worcester, Chief Justice Marshall fashioned indigenous nations as domestic dependent nations subject to federal oversight as well as protection. Though Johnson v. Mclntosh is part of a trilogy, it is presented in property casebooks as standing alone and for the proposition that title in the U.S. system derives from the federal government (Cribbet 1997; Dukeminier and Krier 1998; Singer 1997). Johnson v. Mclntosh explains the origin of property rights in land as being in euro-americans, not indigenous americans, because of a combination of political circumstance, historical circumstance, the superior character of the european, and superior use to which europeans put land (i.e,. agriculture).

Because Johnson v. Mclntosh is presented in property casebooks out of its own legal context, which is to say the trilogy and the ongoing discourse of federal indian law, it comes to signify something other than an objective recitation of lav. It is part legal text, part historical narrative, part creation story, and part symbolic text with a political function. The opinion has definite rationalistic and objective parts that students can identify. But it also has strangely illogical, mythological parts in which Chief Justice Marshall relates a fictional tale. In addition, the opinion contains an explicit admonition against questioning. Since, as Chief Justice Marshall puts it, "the right of society to prescribe those rules by which property may be acquired and preserved is not, and cannot be drawn into question" (Johnson 1832:572).

The basic themes of Marshall's narrative are these: the story starts with European action, specifically the act of crossing the ocean and arriving on the continent of America. As there were indigenous groups on the land, something had to be done to clear the way for European settlement and agriculture. Chief Justice Marshall recites colonial history to conclude that, although indigenous groups had the right to occupancy as against settlers, those rights were subject to extinguishment by the federal government via purchase or alternatively conquest (Johnson 1832:574). There are no land speculators in Justice Marshall's story, nor are the settlers invading, no matter how unfounded their claims about control of the continent. Rather the settlers are cast as innocent but ambitious, at worst pretentious actors who are members of European nations that "on the discovery of this immense continent" were "eager to appropriate to themselves so much of it as they could respectively acquire" (Johnson 1832:572). By the twentieth century, this theme of the settlers as possibly pretentious gets transformed into a national American quality, namely the ability to drive hard Yankee bargains (Cohen 1942:42).

Today, Johnson v. McIntosh is interpreted in law as troubling, yet necessary for U.S. nation building. The typical tack property casebooks take is to reconstruct Chief Justice John Marshall as a heroic federalist valiantly opposed to the Jacksonian Democrats (Berger and Williams 1997; Dwyer and Menell 1998; Singer 1997). In this opposition, Chief Justice Marshall becomes a cultural hero, fighting on behalf of the simulated indian. This canonical view of Chief Justice Marshall ironically takes him out of an american-european vs. indigenous context and puts him instead into a narrower american-eurocentric political context. From this vantage point. Chief Justice Marshall can be applauded for his decision 
despite the unfairness of his representations of indian character (Michaelson 1999: 159; Singer 1997:24). Chief Justice Marshall becomes a man of his time, living in a period when violence against indigenous peoples was viewed as the normal state of things, racialist characterizations (hierarchically understood cultural contingencies) were the order of the day, and what really mattered was Chief Justice Marshall's part in federal politics. The moralistic push of the argument excusing Chief Justice Marshall for not entering into controversies that he ultimately and actually enters into with noticeable vigor - "whether agriculturists, merchants and manufacturers, have a right, on abstract principles, to expel hunters from the territory they possess, or to contract their limits" (Johnson 1832:588) - is that we moderns ought not question much less criticize the past with our presentist values (U.S. v. Sioux Nation 1980:435).

If Chief Justice Marshall's simulated indian is indeed presented without critique as "primitive," or "uncivilized" (Cribbet 1997:37,83), a student segueing in a property casebook from Johnson v. Mclntosh to economic arguments about productivity (Dukeminier and Krier 1998:11-19) is primed for what is often (predictably) the next lesson in the property casebook: learning that indigenous rights are presumably only occupancy rights, and accepting that any and all of the violence that flowed from the U.S. dispossession of indigenous communities was a (necessary) cost of both nation-building and of increasing the efficient (agricultural) use of land (Cribbet 1997).

This particular evolutionary anthropological lesson is a longstanding one in the annals of U.S. legal history, though its terms are today obscured by the late twentieth-century economic language of costs and benefits (Bieder 1990: 164-171; Demsetz 1967; Dukeminier and Krier 1998). But in the unselfconscious nineteenth-century language of manifest destiny, the framework of an evolutionary anthropology comes through loud and clear, even as late as 1930, as an article in the elite Yale Law Journal demonstrates:

A certain liberality of spirit resents any "Americanization" of the Indian, preferring that he be preserved in his ancient life, culture, government, morals, and religion. There is indeed much worth preserving, but it must be recognized that an inexorable destiny dooms the ancient primitive life of the Indian before the advance of our modern civilization (Brown 1930:319).

This language gets modified by the end of the century. It is more optimistic about how much better indigenous peoples have it in the U.S. today than they did in the nineteenth century, as demonstrated by this 1997 law review article published in the equally prestigious Stanford Law Review:

The First Amendment refers to the free exercise of religion, as if religion were wholly separable from other aspects of individuals' lives. Although this isolation of religion from other aspects of life may accurately reflect the Anglo-American perspective of the First Amendment's drafters, it is foreign to the Native American world view (Dussias 1997:806).

To be sure, the 1997 account is written to advocate on behalf of indigenous peoples, whom it nevertheless regards as other. Indigenous peoples get lumped together en masse and implied to possess a stubbornly unchangeable and unchanged, identifiable, single "Native American world view;" indeed, the Native American world view. The article later optimistically (and wrongly) concludes, in a section titled (ironically) "The More Things Change, the More They 
Remain the Same," that "Native Americans are no longer subject to overt government efforts to suppress their traditional beliefs and practices" (Dussias 1997:851). In this tale, the indian is represented as monolithic and simple, but understandable in light of First Amendment jurisprudence. Indeed, in this view, any remaining aspects of the nineteenth century "Indian problem" are reduced to mere problems of translation (Dussias 1997:851-852). Instead of an inexorable destiny dooming "the ancient primitive life of the Indian before the advance of our modern civilization" (Brown 1930:319), the modern civilization has punched out a space where "the Native American world view" can exist (Dussias 1997:806). Exist; but not participate, thrive, influence, or challenge.

\section{A Casebook Example, circa 1997}

In my opinion, no property casebook published today calls the fictional aspect of Chief Justice Marshall's Johnsoin v. McIntosh narrative into question. Ironically, however, whether the casebook editors sympathize (actually they all implicitly sympathize) with indigenous peoples or not, the effect is the same. However, the Cribbet, Johnson, Findley, and Smith (1997) casebook stands alone in explicitly adopting an evolutionist lens for analyzing the relationship between indigenous and non-indigenous communities in the nineteenth century. In notes following Johnson v. McIntosh that discuss the attributes of property, the Cribbet (1997:35) casebook asks: "Would it be fair to say that property, in a legal sense, has any meaning for species other than mankind? Why or why not?" This query replicates the positioning of the indian other near the animal-other, a troubling but recurring motif seen in countless texts (Michaelson 1999), including Johnson v. Mclntosh, and the work of Lewis H. Morgan (1877), a nineteenth-century anthropologist whom the Cribbet casebook (1997:36) cites as a current authority. But, rather than stop there, the editorial voice continues: "Note, however, that even the most primitive human societies have some concept of property" (Cribbet 1997:36).

This remark is followed in the Cribbet (1997) casebook by a 1928 commentary that itself remarks on Morgan's (1877) work detailing what Morgan thought were the major periods of civilization: savagery, barbarism, and civilization (Lowie 1928:551-554). A comment (Morgan's), within a comment (the 1928 comment), within a comment (the 1997 editorial comment) pulling law students from the cusp of the twenty-first century squarely back into the nineteenth, thus distancing the casebook from multiculturalism so as to align it with "anthropology," meaning an evolutionary anthropology whose ideological purpose is to designate whites superior and indigenous peoples inferior (Bieder 1990). Morgan, the Cribbet casebook informs students, places the emergence of the property institution in "the Middle Status of Barbarism-exemplified by the village life of our Southwestern Indians, of the aboriginal Mexicans, and the Peruvians" (Cribbet 1997:36, emphasis added). The excerpt goes on to state that Morgan thought that "among "savages" ... property was inconsiderable" (Cribbet 1997:36). As the Morgan excerpt is intended by casebook editors to raise the issue of "incorporeal property in primitive society," it is followed by this (twentieth-century) editorial note:

The rudimentary concepts of a primitive people are greatly expanded by modern civilizations whose articulate philosophers and molders of public thought must seek rationalizations for their views of so vital a social institution [as property] (Cribbet 1997:37-38). 
Here once again the belief is disseminated that indigenous views - specifically, property systems - are monolithic and simple in comparison to the vast, nuanced, rational U.S. common-law-based system.

The entire discussion of the "primitive" ends several pages later by coupling the evolutionist framework laid out above with the nation-building excuse so often extended to Johnson $v$. Mclntosh. Indeed the editorial voice introduces Johnson v. McIntosh by asking a question not unlike the question a progressive and contextualizing casebook might pose about balancing justice and power (e.g. Singer 1997). The Cribbet casebook asks:

Is there any doubt about the role which property (in this case land) played in the development of the United States into a world power? Could the adjustment of the Indians' claim of ownership have been handled in a different way? What would have been the consequences of the various solutions you may have in mind? (Cribbet 1997:77).

Solutions? To what? From whose point of view? Who is speaking here and to whom? Is there a difference in effect, notwithstanding the radical difference in intention between the more progressive casebooks and this treatment of indigenous interests, other than that the Cribbet casebook invokes a word-"solution"-which makes a chilling allusion to twentieth-century justifications for genocide? How do intentionally progressive anti-racist analyses and an intentionally "scientific" evolutionary analysis that purports to be neutral on the issue of race end up in the same place, asking the same questions, teaching the same binaries? What force is at work here?

\section{Conclusion}

These examples, abbreviated as they are, illustrate that legal narrative uses symbols to disseminate concentrated-mythological-information about what one casebook labels "the case of whiteness" in relation to indigenous peoples (Perea 2000). These symbols are promoted as independent of cultural bias, but they are observably culture-specific as well as ideologically determined.

Indeed, the fact that indigenous rights and interests are discussed in the first-year curriculum only in the first year property course functionally transforms the indian into a signifier whose political function throughout the rest of law school is to make student-initiates of the legal profession skeptical about indigenous property interests on both a broad, ideological level as well as on an unconscious, symbolic level. By signifier I mean that indians in the legal discussions analyzed here stand in for the unrepresentable, thus allowing the non-indigenous settler subject to interpret him or herself and the world known as America as the indian's opposite: representable, coherent, ordered, civilized, efficient, complex, manageable, and so forth (Lacey 1998).

These signifiers also hold strength in their contentlessness (Lacey 1998). Ideas like democracy, human rights, the enemy, or community, for instance, become signifiers to be painted in by the beliefs, ideas, and fantasies of the people to whom they are addressed; these categorical concepts (of which the indian is one) make, or construct, rather than describe the entities to which they refer (Lacey 1998). Because they are contentless, discourses riddled with symbols as signifiers are unstable (Lacey 1998). While they seem to address, maybe even assuage, the 
anxiety or hopelessness that underlies the trauma they stand in for, ultimately they fail in this task. This is because the traumas for which they stand-in this case the genocidal foundations of the U.S. vis-à-vis indigenous communities - conflict irreconcilably with the liberalistic notion of individual equality that stems from the protection of property rights. Sadly, these traumas remain unrepresented, undiscussed, and undiscussable, hidden away in legal pedagogical discourse today.

America in most histories of significance then becomes, as some scholars argue, presented as an ethnically cleansed geography, a place whose beginning was exclusively with Europeans (Vizenor 1999; Weaver 2000). If indigenous communities are mentioned at all it is in the form of the indian signifier - the symbolic indian - which, I argue, is a symbol meant to elucidate something about the allegedly superior non-indigenous path on the continent, not the indigenous path or alternatively the ways in which the paths came together. In this scheme, no reference to or elaboration of the indigenous imagic presence does, or worse, can occur.

Moreover, the symbolic indian can never, by definition, assuage the guilt or trauma of genocide, because it has no content. Indeed, the function of the symbolic indian signifier is to avoid or suppress any discussion of genocide, or even of violence and thus to encourage the view of America as a sparsely settled continent prior to European arrival (Vizenor 1999; Weaver 2000).

It is my observation that students enter law school unaware of the indigenous past, but very willing to learn. But they learn what we teach them. If we continue to teach the genocidal simulations of the indian, we will continue to deprive our collective self of an indigenous imagic presence. We will continue teaching the idea of the ethnically cleansed America. We will also essentially force-through the precedential value of legal opinion and scholarship, which is itself a form of social control-indigenous litigants to adopt the role of the native caught in the past, and thus to place themselves in relation and reaction to modernity. We will continue seeing and encouraging if not requiring representations of the indigenous that refer to golden pasts, or that are otherwise reactionary returns to the past. Our continued existence on the planet is, for the first time in history, called into question. The answers may or may not be in the past; likely they are not. But we need the courage to understand ourselves, to imagine a rich, multiversal future, to question the very images and symbols that we make our laws by, and to ask whether (or not) and how (or not) they continue to serve us.

\section{Cases Cited}

Cherokee Nation v. Georgia, 30 US (5 Pet.) 1 (1831)

Johnson v. McIntosh, 21 US (8 Wheat) 543 (1832)

United States v. Sioux Nation, 448 US 371 (1980)

Worcester v. Georgia, 31 US (6 Pet.) 515 (1832)

\section{References Cited}

Berger, Curtis J., and Joan C. Williams

1997. Property: Land Ownership and Use. New York: Aspen Law \& Business. 
Bieder, Robert E.

1990 "A Brief Historical Survey of the Expropriation of American Indian Remains." In Readings in American Indian Law: Recalling the Rhythm of Survival. Jo Carrillo, ed. Pp. 164-171. Philadelphia: Temple University Press.

Brown, Ray A.

1930 "The Indian Problem and the Law." Yale Law Journal 39(3):307-331.

Carrillo, Jo

2000 "Disabling Certitudes: An Introduction to the Role of Mythologies of Conquest in Law." Florida Journal of Law and Public Policy 12(1):13-31.

1998 Readings in American Indian Law: Recalling the Rhythm of Survival. Philadelphia: Temple University Press.

1996 "Identity as Idiom: Mashpee Reconsidered." Indiana Law Review 28(3):511-45.

Clifford, James

1988 The Predicament of Culture: Twentieth-Century Ethnography, Literature and Art. Cambridge, Mass.: Harvard University Press.

Cohen, Felix

1942 “Original Indian Title." Minnesota Law Review 32(1):28-59.

Cribbet, John E., Corwin W. Johnson, Roger W. Findley, and Ernest E. Smith

1997 Property: Cases and Materials (7th ed.). Westbury, NY: Foundation Press.

Deloria Jr., Vine, and David E. Wilkins

1999 Tribes. Treaties, and Constitutional Tribulations. Austin: University of Texas Press.

Demsetz, Harold

1967 "Toward a Theory of Property Rights." American Economic Review 57 (2):347-57.

Dwyer, John P., and Peter Menell

1998 Property Law and Policy: A Comparative Institutional Perspective. Westbury, NY: Foundation Press.

Dukeminer, Jessie, and James E. Krier

1998 Property (4h ed.). New York: Aspen Law and Business.

Dussias, Allison

1997 "Ghost Dance and Holy Ghost: The Echoes of Nineteenth-Century Christianization Policy in Twentieth-Century Native American Free Exercise Cases." Stanford Law Review 49(4):773-852.

Foucault, Michel

1972 The Archaeology of Knowledge and the Discourse on Language. A. M. Sheridan Smith, trans. New York: Pantheon Books. 
Keenan, Thomas

1997 Fables of Responsibility: Aberrations and Predicaments in Ethics and Politics. Stanford: Stanford University Press.

Lacey, Nicola

1998 Unspeakable Subjects: Feminist Essays in Legal and Social Theory.

Oxford: Hart, Pub., U.S. distributor Evanston, III.: Northwestern University Press.

Legendre, Pierre

1998 "The Other Dimension of Law." In Law and the Postmodern Mind: Essays on Psychoanalysis and Jurisprudence. Peter Goodrich and David Gray Carlson, eds. Pp. 175-192. Ann Arbor: University of Michigan Press.

Lowie, Robert

1928 "Incorporeal Property in Primitive Society." Yale Law Journal 37(5):551563.

Michaelson, Scott

1999 The Limits of Multiculturalism: Interrogating the Origins of American Anthropology. Minneapolis: University of Minnesota Press.

Morgan, Lewis Henry

1877 Ancient Society. New York: Holt \& Co.

Perea, Juan F., Richard Delgado, Angela P. Harris, and Stephanie M. Wildman

2000 Race and Races: Cases and Resources for a Diverse America. St. Paul, MN: West Group.

Singer, Joseph William

1997 Property Law: Rules, Policies, and Practices. New York: Aspen Law \& Business.

Vizenor, Gerald

1999 Manifest Manners: Narratives on Postindian Survivance. Lincoln:

University of Nebraska Press.

Weaver, Jace

Other Words: American Indian Literature, Law, and Culture. Norman: University of Oklahoma Press. 